\title{
More or less equality? Direct Democracy in Europe from 1990 to 2015
}

Brigitte Geißel, Research Unit Democratic Innovations, Goethe-University, 60323 Frankfurt, Germany; EMail: geissel@soz.uni-frankfurt.de

Anna Krämling (corresponding author), Research Unit Democratic Innovations, Goethe-University, 60323 Frankfurt, Germany; E-Mail:kraemling@soz.uni-frankfurt.de; Phone: +49-(0)69-798-36595

Lars Paulus, Research Unit Democratic Innovations, Goethe-University, 60323 Frankfurt, Germany; EMail: I.paulus@soz.uni-frankfurt.de

\begin{abstract}
Within the last decades, western democracies have experienced a rise of inequality, with the gap between lower and upper class citizens steadily increasing and a widespread sentiment of growing inequalities also in the political sphere. Against this background, and in the context of the current "crisis of democracy", democratic innovations such as direct democratic instruments are discussed as a very popular means to bring citizens back in. However, research on direct democracy has produced rather inconsistent results with regard to the question of which effects referenda and initiatives have on equality. Studies in this field are often limited to single countries and certain aspects of equality. Moreover, most existing studies look at the mere availability of direct democratic instruments instead of actual bills that are put to a vote. This paper aims to take a first step to fill these gaps by giving an explorative overview of the outputs of direct democratic bills on multiple equality dimensions, analyzing all national referenda and initiatives in European democracies between 1990 and 2015. How many pro- and contra-equality bills have been put to a vote, how many of those succeeded at the ballot, and are there differences between country groups? Our findings show that a majority of direct democratic bills was not related to equality at all. Regarding the successful bills, we detect some regional differences along with the general tendency that there are more pro- than contra-equality bills. Our paper sheds new light on the question if direct democracy can serve as an appropriate means to complement representative democracy and to shape democratic institutions in the future. The potential of direct democracy in fostering or impeding equality should be an important criterion for the assessment of claims to extend decision-making by citizens.
\end{abstract}

\section{Keywords}

Comparative Analysis; Direct Democracy; Europe; Equality 


\section{Introduction}

In recent times, well-established democracies in Europe and other parts of the world have experienced a considerable decline in conventional political participation as well as growing dissatisfaction with the traditional, representative democratic system in general (Dalton 2004). Along with this, there has been a steady increase of inequality within democratic societies, not only characterized by a growing gap between rich and poor (Gould and Hijzen 2016; Heidenreich 2016), but also partly in political and legal terms. The "crisis of democracy" has sparked an extensive public and scientific debate about alternative forms of political participation and the future of democratic institutions. In the course of this debate, we can among other things - observe an increased call for the expansion of direct democratic instruments such as initiatives and referenda. ${ }^{1}$

However, the question which effects direct democracy has on society is highly disputed among scholars of political science. While some authors emphasize that an expansion of direct democratic instruments has the potential to foster legitimacy and equality (Garry 2013; Feld, Fischer, and Kirchgässner 2010; Frey and Goette 1998), others have a more negative view. They warn that an expansion of direct democratic instruments will give advantages to well-off middle- and upper-class citizens when pursuing their political interests, eventually resulting in even more unequal societies (Merkel 2011; Schäfer and Schoen 2013). Against this background, Töller and Vollmer (2013) emphasize the general necessity to further examine the effects of direct democracy on modern societies - especially for countries other than the US and Switzerland.

This paper will take a look at direct democratic bills in Europe from 1990 to 2015 and provide an explorative overview of how many aimed at promoting or hindering equality - and how many were not related to it at all. Our findings shed new light on the question if direct democracy can serve as a appropriate means to complement representative democracy and to shape democratic institutions in the future. As equality is certainly an central issue for many citizens in western democarcies, the potential of direct democracy in fostering or impeding it should be an important criterion for the assessment of claims to extend decisionmaking by citizens.

\footnotetext{
${ }^{1}$ This increased call for direct democratic instruments can - for example - be observed with populist (right wing) parties throughout European democracies (Bowler et al. 2017). However, it is also prominent in other parts of society and shared by parties and supporters from different political backgrounds.
} 
In this article, we will at first present some theoretical considerations and then proceed by providing an overview of the current literature on direct democracy and equality, pointing out that there is a general disagreement among scholars of political science if direct democratic instruments foster or hinder equality within democratic societies. After this, we present our dataset and elaborate on our coding procedure. In our overview we compare numbers for pro- and contra-equality bills in two categories, namely first for all bills that were put to a vote and second only for those which were successful (i.e. gained a majority and passed a possible quorum). We also differentiatie between different country groups in order to account for regional or resp. cultural differences and arrive at a more fine graded overview. Generally, our results show that a great majority of bills that was put to a direct democratic vote had no obvious connection with equality at all. For those bills that were successful at the ballot, the total number of pro-equality bills is considerably higher than the total number of contra-equality ones - with regional differences emerging especially between Scandinavian countries and Eastern Europe. Finally, the conclusion of the paper will briefly summarize our main findings and propose avenues of further research.

\section{Conceptualizations and Expectations}

Before looking at the outputs of direct democratic votes in terms of equality, we first have to address two important questions from a theoretical background. These questions are:

1) How can equality be conzeptualized, i.e. what understanding of the term do we apply in our analysis? What are the dimensions of equality we are interested in?

2) Why can direct democracy be expected to promote or hinder these dimensions of equality?

Regarding the first question, it can be said that generally the term equality refers to a relationship between two or more reference objects (e.g. A and B) with regard to a certain benchmark X (cf. Alexy 1986; Altwicker 2011; Westen 2016). As this is apparently a rather broad definition of the term, there has been a large discussion among social scientists on how it can be conceptualized.

Traditionally, a large part of this discussion has been around the concepts of "equality in result" and "equal opportunity". A prominent view, especially in the American context, is that "equality is measured in terms of equal opportunity, not equal results, and thus broad disparities in economic and political power do not necessarily reflect a failure of equality" (Devins and Davison M. 1998: 4). However, this view has been challenged by a large number of authors who emphasize the importance of equal results, in the sense of 
closing the gap between disadvantaged and well-off social groups (Strauss 1992; Siegel 1998). The argument here is often that in highly unequal societies, equality of opportunity also decreases and is therefore endangered. As John Rawls (1971: 278) puts it: "fair equality of opportunity means a certain set of institutions that assures similar chances of education and culture to persons similarly motivated [...]. It is these institutions that are put in jeopardy when inequalities of wealth exceed a certain limit, and political liberty likewise tends to lose its value [...]". Against this background, we, for the purpose of this article, understand equality primarily as equality in result, assuming that equal results also enhance equality of opportunity. In other words, we understand equality as closing the gap between those who are well-off (A) and those who are clearly disadvantaged (B) with regard to a certain benchmark (X).

In addition to that, we treat equality as a multidimensional concept. Regarding the effects of direct democracy, most of the literature focusses on aspects of socioeconomic equality. Certainly, socioeconomic equality - i.e. equality with regard to income, education, or health, etc. - is an important issue in modern societies and therewith a central dimension of equality. However, it is not the only one. In direct democratic votes, the majority of the voters decides about political issues, bearing the risk of minorities ${ }^{2}$ being discriminated. Therefore, another point of scientific interest are the implications of direct democratic options and decisions for these groups, containing issues of legal and political equality (see State of the Art below). We want to gain knowledge about direct democratic outputs for equality that is as encompassing as possible. Therefore, we include three dimensions of equality and define them in the following way:

1. Socioeconomic equality: equality regarding the socioeconomic status (aspects such as income, education, health, or property)

2. Legal equality: equality regarding the legal status of the inhabitants of a country ${ }^{3}$

\footnotetext{
2 The term minority is here used in the sense of Lewis (2013). He defines the term as follows: "groups that are or have been historically targeted by the majority. [...] These [...] include minority groups defined by race, color, religion, ethnicity, and national origin. More recently other groups have also gained recognition as valid "political minorities", including groups defined by their sexual orientation, gender identity, age, gender, and disabilities." (Lewis, 2013, 13). The criterion of discrimination is vital at this point, as there are of course minority groups that are highly influential and therefore cannot count as "clearly disadvantaged".

${ }^{3}$ We focus on inhabitants instead of citizens to include all people living in a country and thereby being affected immediately by its law-making. While we do not want to challenge the concept of citizenship - which implies giving citizens more rights than non-citizens -, outputs of direct democratic decisions could increase the legal gap between those two groups even further as non-citizens are (on the national level) not eligible to vote on issues concerning them. Therefore, we follow Lewis (2013) in including them as one of those minority groups that might be disadvantaged in direct democratic votes.
} 
3. Political equality: equality regarding the scope of political influence (especially of minority groups; aspects such as parliamentary tresholds, voting system)

It is important to keep in mind that sometimes it might be necessary to treat groups unequally in order to foster equality in result - to give benefits to those who are worse off at the expense of those who are better off (Sartori, 1992; Altwicker, 2011). ${ }^{4}$ Therefore, all direct democratic bills that aim at making society more equal (by proposing equal or unequal treatment of certain social groups) are considered as proequality.

We now turn to the second question, namely why direct democracy can be expected to have a particular positive or negative output regarding equality in its various dimensions. Direct democracy is defined as popular votes on certain issues - excluding direct elections or recalls of politicians. While those certainly might affect equality as well, the equality-output is very difficult to judge if you're not an expert for the case. The question of the equality-output of direct democratic decisions has been addressed by several authors within the last years and is generally approached from different perspectives.

One prominent argument in the current literature, which is especially promoted by Wolfgang Merkel, is that direct democracy has, above all, a negative impact on - particularly socioeconomic - equality because low socioeconomic status (SES) citizens tend to lose in direct democratic votes. Merkel builds his argument on the empirical observation that it is primarily the well-off upper- and middle classes - not low SES citizens - who participate in direct democratic votes (Merkel 2011: 54). Because of this unequal participation, he concludes that decisions reached through such votes will mainly reflect the socioeconomic interest of the well-off citizens while low SES citizens will generally be disadvantaged. Consequently, direct democracy should have a rather negative impact on socioeconomic equality within modern societies. According to

\footnotetext{
${ }^{4}$ Applied to our context, this means that a given bill that is brought to a popular vote can eventually promote a more equal society, even if it proposes an unequal treatment of particular social groups - depending on the social situation. For example, let us consider a hypothetical bill proposal on a female quota for management positions. Here, we have two groups, namely men and women, who are generally unequal with regard to their presence in - well paid management positions. A female quota now gives women an advantage over men when applying for respective jobs and can, therefore, be considered an unequal treatment. However, given the fact that men are generally overrepresented in management positions, such a quota aims to lead to a more equal society in the sense that the percentage of men and women working in management positions would approximate. As a result, the political output would be equality-promoting in that the bill aims to improve the job situation of a disadvantaged group - here, women in comparison to men - in management positions. Based on this reasoning, we consider direct democratic bills that propose measures aiming to make society more equal as equality-promoting (or pro-equality). As illustrated, this can be the case for both bills that propose equal or unequal treatment of certain social groups, depending on the context.
} 
Merkel and Ritzi (2017), this increasing socioeconomic inequality should also lead to more political inequality - wealthy citizens become even wealthier and require more political influence, while poor ones get poorer and miss the financial means to make themselves heard.

Legal equality can likewise be expected to suffer under direct democratic decisions, as a (usually legally better-off) majority decides upon extending or impeding rights of minorities. In this case, it depends on the willingness of the majority to grant rights to the minority group concerned (see below). This willingness might be especially small if granting rights coincides with granting resources, e.g. concerning issues of citizenship and rights of immigrants. As those are not allowed to vote in national direct democratic decisions and in most cases don't have access to channels of influence, their rights are potentially at risk under direct democracy.

Another approach to the question of how direct democracy impacts equality operates within the median voter theorem. ${ }^{5}$ Here, it has been argued that in the presence of direct democratic instruments, political decision makers have to adapt more to the preferences of the median voter in their decisions than in pure representative systems because otherwise they would risk to be overruled by a popular vote (Töller and Vollmer 2013: 307). Both a direct and an indirect effect of direct democracy comes into play here. Regarding socioeconomic equality, at least in relatively wealthy countries with large middle classes, the median voter is probably the high SES citizen that Merkel assumes and therefore not very likely to vote for extensive redistribution policies. ${ }^{6}$ As a result, we can, similar to Merkel's argument, expect a rather negative output of direct democracy for socioeconomic equality.

The median voter theorem also has implications for the legal and political dimensions of equality. If in the presence of direct democratic instruments political outputs generally will adapt to median voters' preferences - as it is assumed by a number of authors (Töller and Vollmer 2013: 307; Vatter and Danaci 2010; Matsusaka 2004) - then the attitudes of the median voter towards minorities will shape the respective political outputs. For example, in a country where the majority of citizens opposes same-sex marriage, in the presence of direct democratic instruments legal equality for this minority is even less likely to happen than in a purely representative system, as the median voter would vote it down in a direct

\footnotetext{
${ }^{5}$ For classic works and details on the median voter theorem see Black (1948) and Downs (1957).

${ }^{6}$ Based on this reasoning, the presence of direct democratic instruments should also result in less government spending in general because all kinds of spendings for different client groups (not only low SES citizens) that are not in line with median voter preferences should be harder to enforce as compared to a purely representative system (cf. Töller and Vollmer 2013: 307; Vatter 2007: 94).
} 
democratic vote and parliamentarians would fear such a vote and therefore not adopt a bill legalizing it. However, if the opposite is true and the majority of citizens is in favor of the legalization of same-sex marriage while a number of political decision makers are opposed to it, then the presence of direct democratic instruments would much likely have a positive impact on the legal equality of same-sex couples. Similar scenarios are conceivable for political equality and other minority groups such as, for example, voting rights for foreign residents.

The examples above make clear that, from a median voter perspective, it is not possible to formulate general expectations about the outputs of direct democracy in terms of legal and political equality median voter attitudes towards certain minority groups may strongly vary from country to country, region to region, or federal state to federal state (Inglehart and Welzel 2005; Dustmann and Preston 2001; Vatter and Danaci 2010) and accordingly different outputs can be expected.

To sum up, while for socioeconomic equality, one might - at least for wealthy countries with a large middle class - expect a rather negative output of direct democracy, the issue is less clear when it comes to other equality dimensions. Assumptions derived from the median voter theorem point to the importance of taking context into account, as equality-outputs of direct democratic votes probably will vary according to citizens' attitudes. Analyzing those attitudes on the multitude of topics that were put to a vote in our dataset is beyond the scope of this paper. Nevertheless, comparing direct democratic equality-outputs between country groups allows us to detect regional differences while at the same time gain a comprehensive picture. Therefore, we will compare equality-outputs of direct democratic votes between five different European regions - namely Scandinavia, Eastern Europe, Southern Europe, Western Europe and Switzerland - in order to account for historic and cultural differences. This is a rather classical classification of country groups within Europe - with the exception of Switzerland which we look at separately because of its clear special status regarding direct democracy. Before we come to our analysis, we will, in the next section, give a brief overview of the current empirical literature on direct democracy and equality and point to some important research gaps that have, for the most part, been neglected in research so far.

\section{State of the Art}

The effects of direct democracy on equality have been addressed (either explicitly or implicitly) by several political science scholars in recent years - though studies comparing different countries or country groups 
are up to now missing. In this section, we will first present findings of previous studies with regard to socioeconomic equality. In a second step, we will then turn to our two other dimensions, namely political and legal equality, and see how other authors have assessed the impact of direct democracy in this context.

For socioecomic equality, Merkel $(2015,2011)$ - as mentioned earlier - holds a rather skeptical view on the issue. He is by far not the only one who does so. For example, Berry (2014) compares US states with and without direct democratic options regarding their fiscal policies. He concludes that "the main fiscal effect of the voter initiative is not smaller government generally speaking, but it is lower and more unequal education spending" (Berry 2014: 18). Töller and Vollmer (2013), as well as Schäfer and Schoen (2013), come to similar pessimistic conclusions when analyzing a small number of direct democratic votes in Germany such as the educational reform in Hamburg in 2010. They show that resourceful groups are better able to enforce their interests and thereby hinder redistribution, an effect that is reinforced by the disproportionately higher turnout of the better-off.

Feld, Fischer, and Kirchgässner (2010) examine the effects of direct democracy on government welfare spending for Switzerland - a policy field that is naturally closely related to socioeconomic equality. In line with many other studies, the authors compare Swiss cantons with more and with less direct democratic options in law and draw their conclusion from this comparison. They find that cantons with more extensive options invest less in social welfare spending - a finding that is consistent with previous studies in the field (Moser and Obinger 2007; Berry 2009; Feld and Kirchgässner 2000; Wagschal and Obinger 2000; Matsusaka 2004; Freitag and Vatter 2006) - but that this has no effect on the actual level of income equality. In other words, Swiss cantons with less direct democratic options are not "more equal" which brings the authors to draw the conclusion that "Switzerland with its direct democracy at all government levels can hardly be seen as an example where the welfare state is endangered by the existence of direct popular rights" (Feld, Fischer, and Kirchgässner 2010: 834). In this respect, they distance themselves from the mainly pessimistic view on direct democracy and its effects on socioeconomic equality that is promoted by many other authors. 
Finally, Blume, Müller, and Voigt (2009) and Blume and Voigt (2012) conduct a large-n, cross-national analysis of the effects of direct democracy on welfare spending ${ }^{7}$ in which they, similar to the majority of studies in the field, compare countries with and without certain direct democratic options. Their results indicate that direct democracy can have both negative and positive effects on socioeconomic equality depending on which direct democratic instruments are put to practice. ${ }^{8}$ Geißel, Krämling and Paulus (2019) also look at different direct democratic instruments and find that some instruments produce pro-equailty outputs more often then others, however the differences are rather marginal.

We now turn to the effects of direct democracy on legal and political equality. Here, we can find rather mixed results. Gamble (1997), for example, finds that direct democracy has an adverse effect on the rights of US-minorities. Studies by Lewis (2013) and Haider-Markel, Querze, and Lindaman (2007) can in parts confirm this result and emphasize that especially the rights of linguistic minorities and LGBTQ citizens are put in jeopardy under direct democracy in US-American states

However, there is also a number of authors who come to different conclusions and, at least in parts, emphasize positive effects of direct democratic decision making on equality of minorities. For example, Frey and Goette (1998) examine the effect of referenda and initiatives on minority rights in Switzerland and find them to be protected by popular vote. Other studies on minority rights for the US can also not confirm general discrimination of minorities through direct democratic votes and emphasize the importance of context conditions (Donovan and Bowler 1998; Hajnal, Gerber, and Louch 2002). For Switzerland, it seems that the effects of direct democratic votes on minority rights highly depend on how well these minorities are accepted and integrated into society. While a number of studies acknowledges that immigrants tend to be on the losing side in Swiss direct democratic votes, linguistic minorities and homosexual citizens on the other hand are protected and win in these votes (Helbling and Kriesi 2004; Bollinger 2007; Vatter and Danaci 2010; Christmann and Danaci 2012). Vatter (2000:185), in this context, also emphasizes the positive implications of optional referenda for minority groups in Switzerland when

\footnotetext{
${ }^{7}$ The authors not only look at welfare spending but also include other aspects such as total government spending, government efficiency, or level of corruption in their analysis (Blume, Müller, and Voigt 2009; Blume and Voigt 2012).

${ }^{8}$ The results show that countries with national initiatives tend to spend more on welfare (Blume, Müller, and Voigt 2009: 431; Blume and Voigt 2012: 302-303), which can be seen as an indication that there is indeed a positive effect of direct democracy on (socioeconomic) equality. However, the authors - in the same studies - also find that welfare expenditure is lower in countries with mandatory referenda which again seems to speak for the rather negative view on direct democracy as promoted by authors such as Merkel (2015) or Schäfer and Schoen (2013).
} 
he states that "optional referendums and initiatives function as substitute power-sharing instruments for insufficiently integrated minorities".

Overall, the assessment of the current state of the art shows that there is no definite answer to the question of how direct democracy affects equality. Existing studies for socioeconomic equality seem to indicate a rather negative effect of direct democracy, but the picture is far from being entirely clear. For legal and political equality of minority rights, the results of existing studies are even more ambiguous.

Moreover, we can identify at least four considerable research gaps in the field: First, a significant bulk of existing studies either focuses on the US or Switzerland, thus operating in a relatively restricted scope. Cross-national analyses that examine the effects of direct democracy on equality in a comprehensive manner do not exist thus far. ${ }^{9}$ Second, differences between regions are largely ignored. European countries and regions differ in their levels of equality. Some countries experience relatively low levels of equality within society while others have already reached higher levels - a circumstance that might affect the impact of direct democratic instruments on equality in either direction. For example, on the one hand one could imagine less equality-related direct democratic votes in countries with already relatively equal societies, where the need for further equalizing measures might be smaller. ${ }^{10}$ On the other hand, those citizens could value equality even more and therefore initiate equality-fostering votes more often. Besides, the sheer number of direct democratic votes held and their importance in Switzerland might lead to different results there than in the other countries. Third, direct democracy is mostly examined with regard to its effects on either socioeconomic aspects of equality or legal and political equality of minority groups. However, there are no studies that take all of these aspects into account within a coherent analytical framework. Fourth, comparative studies in the field tend to either look at legal options of direct democracy or the mere number of referenda held. The actual outputs of direct democratic bills that are brought to a vote are mostly disregarded. ${ }^{11}$ These research gaps, along with the contradicting results so far, make clear

\footnotetext{
${ }^{9}$ The cross-national analyses by Blume, Müller and Voigt (2009) and Blume and Voigt (2012) only look at certain aspects that are assumed to be related to the socioeconomic dimension of equality.

${ }^{10}$ For example, according to the Gini-Index as a measure for socioeconomic equality, Scandinavian Countries have had relatively low Gini-scores (which indicates high levels of income equality) within the last decade. In contrast, some countries in Eastern and especially Southern Europe have constantly shown higher scores as compared to the rest of the European countries in the same period of time (World Bank 2018). See Appendix for Gini-Indices for all countries.

${ }^{11}$ This is especially problematic for the causal interpretation of the respective results: "While most of the prior literature on the subject attributes contemporary policy differences between initiative and non-initiative states to the causal effect of the institution itself, the historical analysis contained in [...] this paper suggests that things are not so simple. There are obvious pre-treatment differences between would-be initiative and non-initiative states."
} 
that there is indeed a need for a comprehensive overview on the outputs of direct democratic bills regarding different dimensions of equality. Our paper aims to address this issue by looking at all national level, direct democratic bills in Europe from 1990 to 2015. Next, we will present our coding procedure for these bills.

\section{Methodology and Data}

As mentioned, we look at all direct democratic bills at the national level in European democracies in the period from 1990 to 2015. We consider all decisions at the national level and, as opposed to previous studies in the field, we look at actual direct democratic bills and their outputs. We differentiate these outputs according to country groups and the dimension of equality they affect.

First of all, we code the bills in the following way: for each direct democratic bill that was voted on during our sample period, we assess a) if this bill proposes measures that fostered or hampered equality within society $^{12}$ and $b$ ) in case it does, which particular equality dimension was affected. Every bill that proposes measures which would give the greatest benefit to clearly disadvantaged groups will potentially contribute to "closing the gap," in the sense that it would improve the position of those groups relatively to other, better-off, groups. ${ }^{13}$ Therefore, these bills are considered as equality-promoting (or pro-equality). Vice versa, bills that propose measures which primarily benefited other, better-off, groups - and thereby further increased the gap to disadvantaged groups - are considered as equality-hindering (or contraequality). ${ }^{14}$

(Berry 2014: 29). This aspect of pre-treatment effects is problematic for the causal interpretation of (US-) federal state comparisons and shows the need to either expand the scope of studies on direct democracy and (in-)equality or choose a different methodological approach.

12 - or if it does not affect equality at all

${ }^{13}$ The same is true for measures that restrict further benefits for well-off citizens: if, for example, a measure is proposed that would legally restrict manager salaries to a certain amount, this does not benefit lower class citizens per se. It does however prevent well-off citizens (in this case, managers) from further improving their socioeconomic status in relation to low SES citizens. Such a measure would therefore go against a further widening of the socioeconomic gap and is also considered pro-equality.

${ }^{14}$ Our focus is on the gap between clearly disadvantaged and well-off groups. This means that we do not consider bills as equality-promoting if they aim to close, for example, the socioeconomic gap between middle- and upper classes but neglect lower class citizens. Clearly, middle class citizens can hardly be considered a socioeconomically disadvantaged group. Therefore, as long as a bill would not also improve the situation of low SES citizens, it would not contribute to closing the (largest) gap of inequality. Besides, many bills aiming at reducing inequalities do so by benefitting the lower as well as the middle classes. Regarding legal equality, bills count as pro-equality if they give rights to groups that did not enjoy those rights before, while other inhabitants already had them - closing the gap between legally disadvantaged and advantaged groups. Finally, we consider bills as pro-equality in political terms if they aim at increasing the channels of influence for political minorities or decreasing the influence of the most powerful political actors. 
Regarding the socioeconomic equality-dimension, we base our assessment primarily on the question if a particular bill proposes measures that would primarily benefit those groups of society that are worse off when it comes to socioeconomic aspects such as education, income, welfare, or housing. For legal equality, we ask if a particular bill aims to improve the legal situation of certain groups within society that are legally disadvantaged - in the sense that they do not enjoy the same rights as other groups. Examples here are facilitated naturalization for long-term residents without citizenship or the legalization of same-sex marriage. Finally, regarding the political equality-dimension, we assess if a particular bill proposes measures that would improve the situation of political minority groups ${ }^{15}$ so that they can increase their scope of influence and gain more political power - in relation to powerful political mainstream actors. This can for example be the case for measures that strengthen the position of small political parties which represent minority interests, e.g. by introducing proportional representation in parliamentary elections instead of majority representation and thereby increasing their chances to gain seats, ressources and parliamentary influence.

As mentioned earlier, our analysis considers all national-level direct democratic votes that took place between 1990 and 2015 in European democracies. As democratic count all those European countries that - in the respective year - were considered free, according to the well-established Freedom House index. We drew on online-search engines for direct democracy such as www.sudd.ch or www.c2d.ch to collect our data. For the years 1990 to 2015, we arrive at a sample of $n=515$ direct democratic bills in European democracies, of which almost half (240) took place in Switzerland. To give you an impression of the frequency of direct democratic votes over time, Graph 1 entails the number of these votes across all European democracies for each year.

\footnotetext{
${ }^{15}$ Kittilson and Tate (2005: 182) define the term political minority as groups that are "subjected to social, political and economic discrimination in society". However, Lewis (2013: 13) correctly states that the term can also be understood in a broader sense, referring to any group whose interests and characteristics are considered in policy and political discussions. Against this background, we understand political minorities as groups whose political aims and interests significantly differ from mainstream political actors (such as major parties) - with regard to social or ethnical groups they primarily represent (e.g. Black Lives Matter Movement) or issues that they put on their agenda (e.g. Pirate Party).
} 
Graph 1: Direct Democratic Votes in European Democracies 1990-2015 (national level)

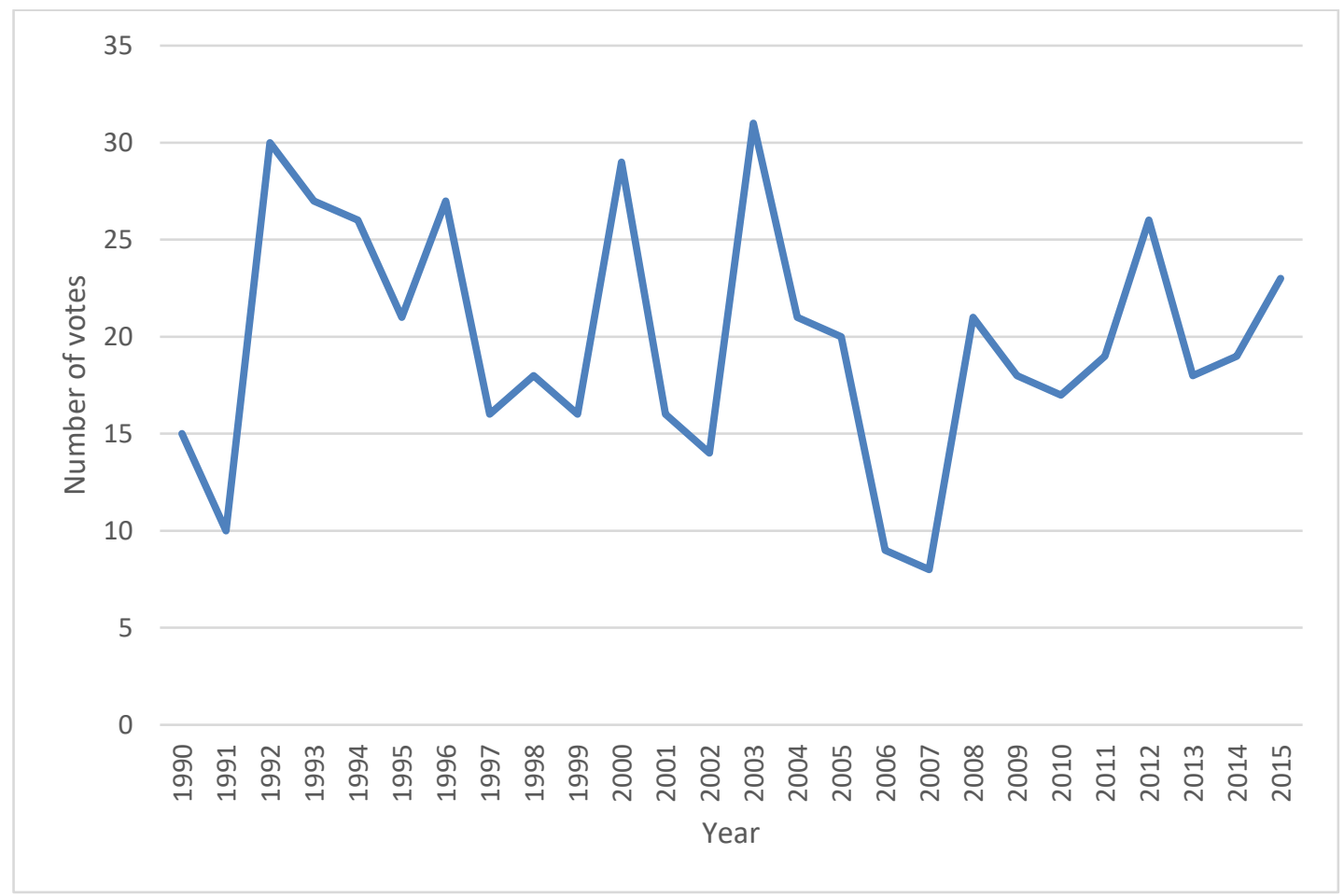

Graph 1 shows that the general impression of a steadily rising popularity of direct democracy does not hold for votes at the national level in the time period. ${ }^{16}$ In contrast, the frequency of votes varies sometimes quite strongly - from year to year, with a minimum of 8 in 2007 and a maximum of 31 in 2003. This also implies that there have been no periods lasting longer than 3 years, in which direct democracy boomed or was rarely used. Additionally, there is variation in the availability of direct democratic options from one country to another. An overview of the countries included in our analysis with information about which direct democratic instruments are available on the national level is presented in table 7 (see appendix). In some cases, for example Norway or the Netherlands, there are no options for direct democracy at the national level at all - except on EU issues. In other countries, such as Italy, Liechtenstein

\footnotetext{
${ }^{16}$ This might in part be due to the inclusion of so many Swiss votes, where direct democracy has a long tradition of being popular.
} 
and Switzerland, referenda take place quite frequently. As a result, we find a lot of cases for these countries.

For our overview, we have to exclude a number of cases out of our total of 515 . First, we have to exclude some bills due to missing data; namely, those bills on which not enough reliable information can be found in order to make a profound judgment what their social, legal, or political consequences would have been (39 cases). Second, bills that propose changes in direct democratic procedures (i.e. put in place new quora, etc.) are also excluded from the analysis because no clear judgement can be made if these bills have had positive or negative impacts on equality (11 cases). ${ }^{17}$ Third, we exclude bills on highly complex issues such as comprehensive tax systems overhauls or complex regulations of privatization ( 23 cases). We do this because, for such comprehensive and complex issues, a clear and sound judgment on the bills' effects on equality can, if at all, only be made through in-depth case-study analysis - something that is not possible for this high number of cases. Fourth, we also exclude bills that involve decisions regarding accession to/exit from international organizations such as the EU, NATO, or the European Single Market (50 cases). The output of the decision to join, for example, the European Union, encompasses so many changes with different effects on and even within our different equality dimensions that it is impossible to code it in a straightforward way. This also holds for bills on adopting entire new constitutions or on independence - a fifth category of cases that we exclude (13 cases). ${ }^{18}$

To sum it up: In order not to distort our results, we only include those direct democratic bills where enough information is available, and we can make a clear and sound judgement if these bills, with regard to our three dimensions, have - or would have - led to more or less equality in the respective country, or if they did not have an equality-output at all.

The following table shows examples of bills that are excluded from our analysis due to the reasons mentioned above:

\footnotetext{
${ }^{17}$ Since our research question is if direct democracy leads to more or less equal political outputs, we cannot - ex-ante - make a judgment of how an expansion or constriction of direct democratic instruments affects equality.

${ }^{18}$ We also exclude bills on decreasing age limits to being eligible to vote or to be voted. On the one hand, they increase legal and political equality because they give political rights to groups that were worse off before (as they did not have these rights). On the other hand, if we coded them as equality promoting, we would have to define a minimum age up to which it is justified to withhold these rights. The same problem arises in the case of bills on punishments for criminals: by committing a crime they lose some of their rights and we do not want to define, for example, how many years of imprisonment are justified for which crimes.
} 
Table 1: Examples of Cases Excluded from Analysis

\begin{tabular}{|l|l|}
\hline Example & Reason for Exclusion \\
\hline $\begin{array}{l}\text { Referendum in Lithuania: 8/27/1994 } \\
\text { capital investments }\end{array}$ & $\begin{array}{l}\text { Missing Data: no information on the actual } \\
\text { content of the bill accessible }\end{array}$ \\
\hline Referendum in San Marino: 7/3/2005 & Bill on direct democratic instruments \\
$\begin{array}{l}\text { Bill on introducing a 40\% approval quorum for } \\
\text { direct democratic votes }\end{array}$ & $\begin{array}{l}\text { Complex Issue: comprehensive reform with } \\
\text { multiple complex aspects to it, no clear } \\
\text { assessment of the effects regarding equality } \\
\text { possible without in-depth case study }\end{array}$ \\
\hline Referendum in Liechtenstein: 10/21/1990
\end{tabular}

After the exclusion of those cases, we arrive at a number of $n=373$ direct democratic bills that are included in our analysis. ${ }^{19}$ For those bills, we make - as mentioned above - a qualitative assessment if the respective bill proposes measures that would promote or hinder equality, with regard to our three equality dimensions - or if it is not related to equality aspects at all. The assessment is based on multiple data sources at hand such as the bill proposal itself, NGO reports, newspaper articles, political science articles and legal text. The coding is based on several key questions that can be found in our codebook in the appendix of this article. In order to increase intercoder reliability, we let multiple researchers do the coding independently from each other and arrived at a congruency of $93.2 \%{ }^{20}$ For illustration purposes, table 2 shows core examples of pro- and contra-equality bills for each equality dimension:

Table 2: Core Examples of Pro- and Contra-Equality Bills

\begin{tabular}{|l|l|l|l|}
\hline & $\begin{array}{l}\text { Socioeconomic } \\
\text { Equality }\end{array}$ & Political Equality & Legal Equality \\
\hline Pro Equality & Hungary: 03/09/2008 & $\begin{array}{l}\text { Liechtenstein: } \\
08 / 11 / 1992\end{array}$ & Ireland: 05/22/2015 \\
\hline
\end{tabular}

\footnotetext{
${ }^{19} \mathrm{~A}$ comparison between excluded, included and all bills regarding their regional distribution and success at the ballot can be found in the Appendix. Unfortunately, the excluded cases were not equally distributed across regions. This is due to, for example, differences in data availability and Eastern European countries joining the EU.

${ }^{20}$ The remaining cases (7\%) were either coded accordingly to the majoritarian decision of the coders or excluded if every coder coded them differently.
} 


\begin{tabular}{|c|c|c|c|}
\hline & $\begin{array}{l}\text { Referendum on } \\
\text { abolition of fees for } \\
\text { higher public education }\end{array}$ & $\begin{array}{l}\text { Referendum on } \\
\text { abolition of the } 8 \% \\
\text { threshold for } \\
\text { parliamentary elections }\end{array}$ & $\begin{array}{l}\text { Referendum on } \\
\text { legalizing same sex } \\
\text { marriage }\end{array}$ \\
\hline Not Equality Related & $\begin{array}{l}\text { Switzerland: } \\
\text { 04/01/1990 } \\
\text { Initiative against } \\
\text { highway between Biel } \\
\text { and Solothurn/Zuchwil }\end{array}$ & $\begin{array}{l}\text { Liechtenstein: } \\
03 / 10 / 2002 \\
\text { Referendum on raising } \\
\text { funds for the Little Big } \\
\text { One music festival }\end{array}$ & $\begin{array}{l}\text { Lithuania: } 06 / 14 / 1992 \\
\text { Referendum on the } \\
\text { withdrawal of Soviet } \\
\text { troops from Lithuania } \\
\text { by end of } 1992\end{array}$ \\
\hline Contra Equality & $\begin{array}{l}\text { Switzerland: } \\
09 / 27 / 1998 \\
\text { Referendum on } \\
\text { reduction of pensions } \\
\text { for orphans and } \\
\text { widows }\end{array}$ & $\begin{array}{l}\text { Poland: 09/06/2015: } \\
\text { Introduction of } \\
\text { majoritarian voting } \\
\text { system for } \\
\text { parliamentary elections } \\
\text { instead of proportional } \\
\text { voting system }\end{array}$ & $\begin{array}{l}\text { Slovakia: 02/07/2015 } \\
\text { Referendum on } \\
\text { banning adoption by } \\
\text { same-sex couples }\end{array}$ \\
\hline
\end{tabular}

It is important to keep in mind that we base our judgment purely on the political output that each bill (would have) produced, not on the actual outcome. ${ }^{21}$ Nevertheless, we draw on multiple data sources in order to understand the social and political contexts of each bill, so that a sound judgment is possible. For example, there was a rather prominent referendum in Italy that took place in June 1995 and in which voters were, among other things, asked if the ownership of private television channels should be limited to one per person. At first glance, this bill proposal does not necessarily seem particularly equality-related, but considering the political context in Italy at the time, a different picture emerges: in fact, at the time the referendum was held, all three of Italy's private television channels were owned by Finivest, a company founded by and in control of Silvio Berlusconi (Tagliabue 1995; Capretti 2001: 155-166). At the time, Berlusconi used his monopoly position in the media sector for his own political ambitions - airing TV advertisements and shows that would help his political agenda (Capretti 2001: 156-157). The referendum was de facto an attempt by left-wing opposition forces to break up the concentration of television ownership so that Berlusconi would lose his monopoly position in the Italian media industry (Tagliabue 1995; Vospernik 2014). Naturally, Berlusconi and his supporters were strongly opposed to this bill proposal because - if successful - it would have weakened his dominant position and, in turn, benefited opposition

\footnotetext{
${ }^{21}$ In order to assess policy outcomes, in-depth case studies would be necessary which is beyond the scope of this paper. Therefore, we focus on assessing the bills' outputs.
} 
forces and potentially increased their scope of political influence. Against this background, we code this particular bill proposal - which was voted on in the June 1995 referendum - as pro-equality. This is of course just one out of many examples but it demonstrates the need to look at the actual content of direct democratic bills in their political context (if possible) in order to make a sound judgment regarding their equality output.

Finally, it is important that in our tabulation, we draw a general distinction between two levels of analysis, namely a bill-level and an output-level. The bill-level relates to all included bills that were put to the vote ( $n=373)$ - regardless of whether they succeeded or failed. For the output-level, we only consider those bills that were adopted ${ }^{22}$ and, as a consequence, had an actual political output ( $\left.n=129\right)$. This procedure allows us to generate a finer graded overview of how many of our total bills were pro/contra equality and how many of those were actually adopted. For both the bill- and output-level, we code 1 if the bill was proequality, -1 if it was contra-equality, and 0 if it did not have an effect on any of our equality dimensions. Additionally, we compare results between five different country groups to account for regional differences.

\section{Overview - More or Less Equality?}

For the presentation of our overview, we proceed in two steps. In a first step, we will give a general overview of how many bills, both on the bill- and output-level, were pro-/contra-equality and how many were not related to equality aspects at all. We do this for all countries under examination but also distinguished between classic country groups, namely Scandinavia, Eastern Europe, Southern Europe, Western Europe and Switzerland (since it clearly has an exceptional status regarding direct democracy). As mentioned in the State of the Art, European countries differ in their level of equality and the frequency of direct democratic votes. This might affect the impact of direct democratic instruments on equality.

In a second step, we will paint a more fine graded picture and look at our individual equality dimensions in order to assess if certain dimensions are more often affected (positively or negatively) by public decision making in direct democratic votes.

\footnotetext{
${ }^{22}$ Bills that were approved by the citizens and passed a (possible) quorum.
} 
Tables 3 and 4 show - for all country groups - how many bills were pro-/contra-equality ones and how many were not related to equality aspects at all. The tables provide information on both the bill- and output-level.

Table 3: Pro- and Contra-Equality Bills (all Equality-Dimensions; Bill-level)

\begin{tabular}{|l|l|l|l|l|l|l|}
\hline & Switzerland & Scandinavia & $\begin{array}{l}\text { Eastern } \\
\text { Europe }^{24}\end{array}$ & $\begin{array}{l}\text { Southern } \\
\text { Europe }^{25}\end{array}$ & $\begin{array}{l}\text { Western } \\
\text { Europe }^{26}\end{array}$ & $\begin{array}{l}\text { All } \\
\text { Countries }\end{array}$ \\
\hline $\begin{array}{l}\text { Pro Equality } \\
(+\mathbf{1})\end{array}$ & 54 & 3 & 16 & 8 & 9 & 90 \\
\hline $\begin{array}{l}\text { Not Equality } \\
\text { Related (0) }\end{array}$ & $125.71 \%)$ & $(50 \%)$ & $(29.09 \%)$ & $(15.09 \%)$ & $(18.37 \%)$ & $(24.13 \%)$ \\
\hline $\begin{array}{l}\text { Contra Equality } \\
(-1)\end{array}$ & $(60.95 \%)$ & 3 & 27 & 40 & 37 & 235 \\
\hline Total & $(13.33 \%)$ & $(0 \%)$ & $(49.09 \%)$ & $(75.47 \%)$ & $(75.51 \%)$ & $(63 \%)$ \\
& 210 & 6 & 12 & 5 & 3 & 48 \\
& $(100 \%)$ & $(100 \%)$ & $(21.82 \%)$ & $(9.43 \%)$ & $(6.12 \%)$ & $(12.87 \%)$ \\
\hline
\end{tabular}

Table 4: Pro- and Contra-Equality Outputs (all Equality-Dimensions; Output-level)

\begin{tabular}{|l|l|l|l|l|l|l|}
\hline & Switzerland & Scandinavia & $\begin{array}{l}\text { Eastern } \\
\text { Europe }\end{array}$ & $\begin{array}{l}\text { Southern } \\
\text { Europe }\end{array}$ & $\begin{array}{l}\text { Western } \\
\text { Europe }\end{array}$ & $\begin{array}{l}\text { All } \\
\text { Countries }\end{array}$ \\
\hline $\begin{array}{l}\text { Pro Equality } \\
(+\mathbf{1})\end{array}$ & $\begin{array}{l}14 \\
(19.44 \%)\end{array}$ & 3 & 3 & 2 & 4 & 26 \\
$(75 \%)$ & $(25 \%)$ & $(11.11 \%)$ & $(17.39 \%)$ & $(20.16 \%)$ \\
\hline $\begin{array}{l}\text { Not Equality } \\
\text { Related (0) }\end{array}$ & 47 & 1 & 5 & 15 & 17 & 85 \\
\hline $\begin{array}{l}\text { Contra Equality } \\
(-1)\end{array}$ & $11.28)$ & $(25 \%)$ & $(41.67 \%)$ & $(83.33 \%)$ & $(73.91 \%)$ & $(65.89 \%)$ \\
\hline Total & $(15.28 \%)$ & 0 & 4 & 1 & 2 & 18 \\
& 72 & 4 & $(33.33 \%)$ & $(5.56 \%)$ & $(8.7 \%)$ & $(13.95 \%)$ \\
\hline
\end{tabular}

When we take a look at the tables above, it first becomes clear that on the output-level (meaning for those bills that were successful and had an actual political output), a great majority of bills had no obvious connection with equality at all. This is true for over $65 \%$ of all successful bills. The only exception is Scandinavia, where only $25 \%$ of all bills were not related to our equality dimensions - but this might also stem from the fact that there were only 6 bills in total voted upon in this region during the time period from 1990 to 2015.

\footnotetext{
${ }^{23}$ Denmark, Finland, Iceland, Norway, Sweden

${ }^{24}$ Bulgaria, Croatia, Czech Republic, Estonia, Hungary, Latvia, Lithuania, Poland, Romania, Serbia, Slovakia, Slovenia

${ }^{25}$ Andorra, Cyprus, Greece, Italy, Malta, Portugal, San Marino, Spain

${ }^{26}$ Austria, France, Ireland, Liechtenstein, Luxembourg, Netherlands, United Kingdom
} 
Regarding those bills that we coded as equality-affecting in their output, the total number of successful pro-equality bills is considerably higher than the total number of successful contra-equality ones (26 vs. 18). In the single regions differences are smaller, with the Scandinavian countries being the only ones were all adopted equality-affecting bills were pro-equality. On the other hand, there were more successful contra-equality bills than pro-equality ones in Eastern Europe. These variations across European regions point to the importance of taking contextual effects into account when evaluating direct democracy in general: while the overall picture of European direct democracy at the national level looks rather optimistic with regard to the number of bills producing equality-outputs, we cannot draw the conclusion that direct democracy per se tends to foster or hinder equality in every country. Therefore, our first core finding is: for the time period from 1990 to 2015, the output of direct democratic votes was more often pro than contra equality in all European democracies taken together. This seems to support those scholars who emphasize positive effects of direct democracy on equality (e.g. Gamble 1997; Feld, Fischer, and Kirchgässner 2010). Nevertheless, there was also a considerable number of successful contra-equality bills. This, and above all the results from younger democracies in Eastern Europe, shows that there are also risks for equality when it comes to direct democratic instruments, giving some credit to their critics (e.g. Merkel 2011; Schäfer and Schoen 2013).

When interpreting these results, it is important to keep in mind that single equality-affecting bills differ in the degree to which they foster or hinder equality. For example, an increase of $2 \%$ in contributions to unemployed people as well as a decrease of $10 \%$ would each count as one bill fostering/hindering socioeconomic equality. But of course, the negative output-effect of the second bill would be much larger than the positive output-effect of the first one. Therefore, a comparison of the shere numbers of equalityaffecting bills does not allow for conclusions about overall positive or negative effects of direct democracy on equality. All we can say based on those numbers is that direct democratic votes more often increased than decreased equality in their output.

When we not only consider the output-level, but also look at the bill-level, i.e. all bills that were put to a direct democratic vote regardless of whether they were successful or not, we discover another interesting finding. We can see that - even though the majority of bills is still not related to our definition of equality at all - almost twice as many pro-equality bills were put to a vote than contra ones. This finding holds for all country groups, even for Eastern Europe. Therefore, on a bill-level, the positive differential in direct democratic votes affecting equality could have been much more distinct than it turned out to be on the 
output-level. Looking at the single regions, besides the obvious turnaround of Eastern Europe, pro-equality bills especially seemed to have a hard time at the polls compared to their contra-equality counterparts in Switzerland: out of the 54 bills that proposed pro-equality measures, 14 were successful and implemented. At the same time, from 28 bills proposing contra-equality measures, an almost equal number (11) was successful. As a matter of fact, it seems as if the positive effect that most of the bills would have had on equality (if they had been successful) got lost when voters decided upon those proposals in Eastern Europe and Switzerland. Compared to that, they have a better record in Southern and Western Europe and above all in Scandinavia, where all pro-equality bills were adopted (but again, only 6 votes took place there).

We now turn to our equality dimensions. Tables 5 and 6 show - for all countries - how many pro- and contra-equality bills were there on the different equality dimensions. Respective tables for the country groups can be found in the appendix of this paper.

Table 5: Pro- and Contra-Equality Bills Separated in Different Equality Dimensions (Bill-level)

\begin{tabular}{|l|l|l|l|l|}
\hline & Socioeconomic & Political & Legal & Total \\
\hline Pro equality (+1) & 48 & 14 & 28 & 90 \\
& $(12.87 \%)$ & $(3.75 \%)$ & $(7.51 \%)$ & $(24.13 \%)$ \\
\hline Not Related (0) & 309 & 348 & 324 & 235 \\
& $(82.84 \%)$ & $(93.30 \%)$ & $(86.86 \%)$ & $(63 \%)$ \\
\hline Contra Equality (-1) & 16 & 11 & 21 & 48 \\
& $(4.29 \%)$ & $(2.95 \%)$ & $(5.63 \%)$ & $(12.87 \%)$ \\
\hline Total Bills & 373 & 373 & 373 & 373 \\
& $(100 \%)$ & $(100 \%)$ & $(100 \%)$ & $(100 \%)$ \\
\hline
\end{tabular}

Table 6: Pro- and Contra-Equality Outputs Separated in Different Equality Dimensions (Output-level)

\begin{tabular}{|l|l|l|l|l|}
\hline & Socioeconomic & Political & Legal & Total \\
\hline Pro equality (+1) & 16 & 3 & 7 & 26 \\
& $(12.40 \%)$ & $(2.33 \%)$ & $(5.43 \%)$ & $(20.16 \%)$ \\
\hline Not Related (0) & 109 & 121 & 113 & 85 \\
& $(84.50 \%)$ & $(93.80 \%)$ & $(87.60 \%)$ & $(65.89 \%)$ \\
\hline Contra equality (-1) & 4 & 5 & 9 & 18 \\
& $(3.10 \%)$ & $(3.88 \%)$ & $(6.98 \%)$ & $(13.95 \%)$ \\
\hline Total Bills & 129 & 129 & 129 & 129 \\
& $(100 \%)$ & $(100 \%)$ & $(100 \%)$ & $(100 \%)$ \\
\hline
\end{tabular}


If we look at Table 5, we can see that on the bill-level, it is especially the socioeconomic dimension of equality that produces more pro- than contra-equality bills. Here, $12.87 \%$ of bills were equality-promoting (pro equality) while only $4.29 \%$ were equality-hindering (contra equality). For the other dimensions, the differential is also positive, but not as much as for socioeconomic equality.

Looking at table 6, we once again see that the total number of successful pro-equality bills exceeds the number of contra-equality ones. Nevertheless, this overall positive picture is only due to the socioeconomic dimension: while the number of pro-equality bills on this dimension is four times higher than the number of contra-equality ones, the opposite is true for political and legal equality. Here, we actually detect more successful contra-equality bills than pro-equality ones.

\section{Interpretation}

What do we make of these results? First, contradicting the opponents of direct democracy in the previous literature, there does not seem to be a purely negative effect of direct democratic bills on equality in European democracies in general. In fact, for all the successful direct democratic votes - where the bills produced an actual political output - pro-equality bills outnumber contra-equality ones. This result is especially interesting since it stands in contrast with the somewhat negative view on direct democracy that is advocated by a large number of authors. These previous studies arrive at their negative evaluations either based on state comparisons for the US and Switzerland, or theoretical arguments with an emphasis on single, prominent cases where direct democratic decisions have fostered inequality such as the minaret decision in Switzerland (2009) or the educational reform in Hamburg, Germany (2010) (Merkel 2011; Töller and Vollmer 2013; Schäfer and Schoen 2013). It turns out that the negative view on direct democracy and its impact on equality cannot hold for our more comprehensive analytical framework where all nationallevel direct democratic decisions in Europe from 1990 to 2015 are considered. This points to the importance of studying the effects of direct democracy in a broader context to be able to acquire profound knowledge on its performance before judging it.

Second, looking at the different dimensions of equality, patterns in certain regions turn out to be decisive. At first sight, there seems to be a positive differential between adopted direct democractic bills fostering socioeconomic equality and those hindering it, while political and legal equality seem to be diminished more often under popular democracy than they are increased. However, if we look at the country groups (see appendix), we can detect that the positive picture regarding socioeconomic equality is mainly due to 
Switzerland and Eastern Europe. All other country groups have more or less balanced numbers or no successful bills affecting socioeconomic equality at all.

The same is true for the negative outputs regarding political and legal equality: them overwhelming the positive ones stems only from Eastern Europe and Switzerland. In the Scandinavian countries, the output on those dimensions is exclusively positive, while numbers are more or less balanced in Southern and Western Europe. Therefore, whereas the overall picture suggests negative implications for legal and political equality in a majority of direct democratic votes, deeper investigation shows that this seems to be true only for specific regions of the continent. In most of the country groups, negative outputs are not more frequent than positive ones. This once again points to the importance of differentiating between regions in addition to the analysis of European democracies in total. After doing so, one can see that Switzerland and Eastern Europe account for the differences between the single dimensions - interestingly in opposite directions, with more successful bills fostering socioeconomic equality while at the same time also more adopted bills hindering legal and political equality. When looking at the other regions, these differences decrease and the numbers of successful pro- and contra-equality bills are more or less balanced across all of our dimensions, slightly tending to the positive side. In order to make a profound evaluation of the effects of direct democracy on equality in Europe, it is therefore crucial to take differences between contexts into account.

Third and last, if we look at all bill proposals that were put to a direct democratic vote, contra-equality bills are outnumbered by the pro-equality ones to an even larger degree. This is especially obvious when looking at the socioeconomic dimension of equality: there are far more pro-equality bills (48) than contraequality ones (16) on this dimension, while differences are smaller in comparison for legal and political equality. However, as mentioned earlier, this positive trend is slowed down a bit when looking at the output-level (and turned on its head in Eastern Europe): while much more pro-equality bills are put to a direct democratic vote, they seem to have difficulties gaining a majority and succeeding at the ballot.

\section{Conclusion}

This paper has examined the question if direct democractic bills in Europe have promoted or hindered equality within the last decades. In order to create an explorative overview on the issue, we drew on a dataset of all national-level, direct democratic bills in European democracies from 1990 to 2015. We then 
assessed for each decision if it had a promoting or hindering output in terms of equality. ${ }^{27}$ In contrast to previous studies in the field, we looked at actual direct democratic bills in a large number of countries, and we considered multiple dimensions of equality, namely socioeconomic, political, and legal equality. Additionally, we differentiated between country groups to get an impression if the general results can be found in all regions or if they depend on the social and political context.

Our study has shown that direct democracy had no particular negative output regarding equality in European democracies within those 25 years. Of all successful bills that were put to a direct democratic vote, ${ }^{28}$ the pro-equality bills outnumber the contra-equality ones. This finding neither supports those authors with a relatively skeptical view on direct democracy, nor those with an enthusiastic one (as there were also a considerable number of contra-equality outputs). However, there are differences concerning the single equality dimensions: while there are significantly more pro-equality bills for socioeconomic equality that have been passed and adopted, political and legal equality seem to be diminished under direct democratic votes more often. The investigation of country groups reveals that the first finding mainly stems from direct democratic votes in Switzerland and Eastern Europe - as does the second. Numbers in the other country groups are more or less balanced across all dimensions, with a tendency towards pro-equality.

The results of this paper can serve as a starting point for a variety of further research projects. First and most generally, our study shows the need for future research in the field to broaden the analytical framework and not only focus on state comparisons of single countries and/or individual prominent direct democratic decisions. Indeed, from our comprehensive analyses, we can neither confirm a clearly negative nor a clearly positive output from direct democratic decisions for equality. Future research can analyze if our results also hold for a longer period, at the sub-national level or in different parts of the world.

Furthermore, another topic of future investigation can be the differentiation between direct democratic instruments. Although the overall outputs regarding equality are more or less balanced, bottom-up instruments might result in totally different outputs than top-down ones do. This would also shed some light on the nature of initiatives: which groups initiate direct democratic votes, and what are their purposes?

\footnotetext{
${ }^{27}$ Alternatively, if it did not have any effect at all

${ }^{28}$ Bills that were approved by the citizens and passed a (possible) quorum
} 


\section{Acknowledgements}

We thank the German Research Foundation (DFG) for their funding of the research project 'Inequality and Direct Democracy in Europe'.

\section{Conflict of Interests}

The authors declare no conflict of interests. 


\section{Literature}

Alexy, Robert. 1986. Theorie Der Grundrechte. 7th ed. Berlin: Suhrkamp.

Altwicker, Tilmann. 2011. Menschenrechtlicher Gleichheitsschutz. Wiesbaden: Springer VS.

Berry, Christopher R. 2009. "Direct Democracy and Redistribution." Working Paper. University of Chicago.

- - . 2014. "Direct versus Representative Democracy: Reassessing the Fiscal Effects."

Black, Duncan. 1948. "On the Rationale of Group Decision-Making." The Journal of Political Economy 56

(1): 23-34.

Blume, Lorenz, Jens Müller, and Stefan Voigt. 2009. "The Economic Effects of Direct Democracy-a First Global Assessment." Public Choice 140 (3): 431-61.

Blume, Lorenz, and Stefan Voigt. 2012. "Institutional Details Matter-More Economic Effects of Direct Democracy." Economics of Governance 13 (4): 287-310.

Bollinger, Christian. 2007. "Minderheiten in Der Direkten Demokratie." In Direkte Demokratie, by Markus Freitag and Uwe Wagschal, 419-46. Berlin: Lit Verlag.

Bowler, Shaun, David Denemark, Todd Donovan, and Duncan McDonnell. 2017. "Right-Wing Populist Party Supporters: Dissatisfied but Not Direct Democrats." European Journal of Political Research 56 (1): 70-91.

Capretti, Anna. 2001. Öffnung Der Machtstrukturen Durch Referenden in Italien. Frankfurt am Main: Europäischer Verlag der Wissenschaft.

Christmann, Anna, and Deniz Danaci. 2012. "Direct Democracy and Minority Rights: Direct and Indirect Effects on Religious Minorities in Switzerland." Politics and Religion 5 (1): 133-60.

Dalton, Russell J., ed. 2004. Democratic Challenges, Democratic Choices. The Erosion of Political Support in Advanced Industrial Democracies. Oxford: Oxford University Press.

Devins, Neal, and Douglas Davison M. 1998. "Introduction: The Pursuit of Equality." In Redefining Equality, by Neal Devins and Douglas Davison M., 1-12. New York: Oxford University Press.

Donovan, Todd, and Shaun Bowler. 1998. "Direct Democracy and Minority Rights: An Extension." American Journal of Political Science 42 (3): 1020-24.

Downs, Anthony. 1957. An Economic Theory of Democracy. New York: Harper \& Brothers.

Dustmann, Christian, and lan Preston. 2001. "Attitudes to Ethnice Minorities, Ethnice Context and Location Decisions." The Economic Journal, no. 111: 353-73.

Eurostat. 2018. "Gini-Koeffizient Des Verfügbaren Äquivalenzeinkommens." European Commision. http://appsso.eurostat.ec.europa.eu/nui/show.do?dataset=ilc_di12\&lang=de.

Fatke, Matthias. 2015. "Participation and Political Equality in Direct Democracy: Educative Effect or Social Bias." Swiss Political Science Review 21 (1): 99-118.

Feld, Lars P., Justina A. V. Fischer, and Gebhard Kirchgässner. 2010. "The Effect of Direct Democracy on Income Redistribution: Evidence for Switzerland." Economic Inquiry 48 (4): 817-40.

Feld, Lars P., and Gebhard Kirchgässner. 2000. "Direct Democracy, Political Culture, and the Outcome of Economic Policy: A Report on the Swiss Experience." European Journal of Political Economy 16 (2): 287-306.

Freitag, Markus, and Adrian Vatter. 2006. "Initiatives, Referendums, and the Tax State." Journal of European Public Policy 13 (1): 89-112.

Frey, Bruno S., and Lorenz Goette. 1998. "Does the Popular Vote Destroy Civil Rights?" American Journal of Political Science 42 (4): 1343-48.

Geißel, Brigitte, Anna Krämling, and Lars Paulus. 2019."It Depends... Different Direct Democratic Instruments and Equality in Europe from 1990 to 2015." Politics and Governance, forthcoming.

Gamble, Barbara S. 1997. "Putting Civil Rights to a Popular Vote." American Journal of Political Science 41 (1): 245-69. 
Garry, John. 2013. “Direct Democracy and Regional Integration: Citizens' Perceptions of Treaty Implications and the Irish Reversal on Lisbon." European Journal of Political Research 52 (1): 94118.

Gerber, Elisabeth R., and Simon Hug. 2002. "Minority Rights and Direct Legislation: Theory, Methods, and Evidence." http://www.unige.ch/ses/spo/static/simonhug/mrdd/joprr.pdf.

Gould, Eric D., and Alexander Hijzen. 2016. "Growing Apart, Losing Trust? The Impact of Inequality on Social Capital." IMF Working Papers 16(176). http://www.elibrary.imf.org/doc/IMF001/236439781475529487/23643-9781475529487/Other_formats/Source_PDF/236439781475529531.pdf.

Haider-Markel, Donald P., Alana Querze, and Kara Lindaman. 2007. "Lose, Win, or Draw?: A Reexamination of Direct Democracy and Minority Rights." Political Research Quarterly 60 (2): 304-14.

Hajnal, Zoltan L., Elisabeth R. Gerber, and Hugh Louch. 2002. "Minorities and Direct Legislation: Evidence from California Ballot Proposition Elections." The Journal of Politics 64 (1): 154-77.

Heidenreich, Martin. 2016. "The Europeanization of Income Inequality Before and During the Eurozone Crisis: Inter-, Supra- and Transnational Perspectives." In Exploring Inequality in Europe: Diverging Income and Employment Opportunities in the Crisis, edited by Martin Heidenreich, 22-47. Cheltenham \& Northampton: Edward Elgar.

Helbling, Marc, and Hanspeter Kriesi. 2004. "Staatsbürgerverständnis Und Politische Mobilisierung: Einbürgerungen in Schweizer Gemeinden." Swiss Political Science Review 10 (4): 33-58.

Inglehart, Ronald, and Christian Welzel. 2005. Modernization, Cultural Change, and Democracy: The Human Development Sequence. Cambridge: Cambridge University Press.

Kern, Anna, and Marc Hooghe. 2017. "The Effect of Direct Democracy on the Social Stratification of Political Participation: Inequality in Democratic Fatigue?" Comparative European Politics January: 1-21.

Kittilson, Miki Caul, and Katherine Tate. 2005. "Political Parties, Minorities, and Elected Office: Comparing Opportunities for Inclusion in the United States and Britain." In The Politics of Democratic Inclusion, edited by Christina Wolbrecht. Philadelphia: Temple University Press.

Lewis, Daniel. 2013. Direct Democracy and Minority Rights: A Critical Assessment of the Tyranny of the Majority in the American States. New York: Routledge.

Matsusaka, John G. 2004. For the Many or the Few. The Initiative, Public Policy, and American Democracy. Chicago: University of Chicago Press.

Merkel, Wolfgang. 2011. "Volksabstimmungen: Illusion Und Realität." Aus Politik Und Zeitgeschichte 61 (44-45): 47-55.

- - . 2015. Nur Schöner Schein? Demokratische Innovationen in Theorie Und Praxis. OBS-Arbeitsheft 80. Berlin: Friedrich-Ebert-Stiftung.

Merkel, Wolfgang, and Claudia Ritzi. 2017. Die Legitimität Direkter Demokratie. Wie Demokratisch Sind Volksabstimmungen? Wiesbaden: Springer VS.

Moser, Julia, and Herbert Obinger. 2007. "Schlaraffenland Auf Erden? Auswirkungen von Volksentscheiden Auf Die Sozialpolitik." In Direkte Demokratie, by Markus Freitag and Uwe Wagschal, 331-62. Berlin: Lit Verlag.

Rawls, John. 1971. A Theory of Justice. Cambridge: Harvard University Press.

Sartori, Giovanni. 1992. "Gleichheit." In Demokratietheorie, 326-54. Darmstadt: Wissenschaftliche Buchgesellschaft.

Schäfer, Armin, and Harald Schoen. 2013. "Mehr Demokratie, Aber Nur Für Wenige? Der Zielkonflikt Zwischen Mehr Beteiligung Und Politischer Gleichheit." Leviathan 41 (1): 94-120.

Siegel, Reva. 1998. "Civil Rights Reform in Historical Perspective: Regulating Martial Violence." In Redefining Equality, by Neal Devins and Douglas Davison M., 29-50. New York: Oxford University Press. 
Strauss, David. 1992. "The Illusory Distinction Between Equality of Opportunity and Equality of Result." William \& Mary Law Review 34 (1): 171-88.

Tagliabue, John. 1995. "Italien Referendum May Break Up Berlusconi's TV Interests." New York Times, 1995. https://www.nytimes.com/1995/06/11/world/italian-referendum-may-break-upberlusconi-s-tv-interests.html.

Töller, Annette, and Annette Vollmer. 2013. "Wem Nützt Direkte Demokratie? Policy-Effekte Direkter Demokratie Und Folgerungen Für Die Forschung Zu Deutschland." Zeitschrift Für Vergleichende Politikwissenschaft 7 (4): 299-320.

Vatter, Adrian. 2000. "Consensus and Direct Democracy: Conceptual and Empirical Linkages." European Journal of Political Research 38 (2): 171-92.

- - . 2007. "Direkte Demokratie in Der Schweiz: Entwicklungen, Debatten, Wirkungen." In Direkte Demokratie: Bestandsaufnahmen Und Wirkungen Im Internationalen Vergleich, by Markus Freitag and Uwe Wagschal, 71-113. Münster: Lit Verlag.

Vatter, Adrian, and Deniz Danaci. 2010. "Mehrheitstyrannei Durch Volksentscheide? Zum Spannungsverhältnis Zwischen Direkter Demokratie Und Minderheitenschutz." Politische Vierteljahresschrift 51 (2): 205-22.

Vospernik, Stefan. 2014. Modelle der direkten Demokratie. Volksabstimmungen im Spannungsfeld von Mehrheits- und Konsensdemokratie - Ein Vergleich von 15 Mitgliedsstaaten der Europäischen Union. Baden-Baden: Nomos.

Wagschal, Uwe, and Herbert Obinger. 2000. "Der Einfluss Der Direktdemokratie Auf Die Sozialpolitik." Politische Vierteljahresschrift 41 (3): 466-97.

Westen, Peter. 2016. Speaking of Equality: An Analysis of the Rhetorical Force of 'Equality' in Moral and Legal Discourse. Princeton: Princeton University Press.

World Bank. 2018. "GINI Index (World Bank Estimate)." The World Bank. https://data.worldbank.org/indicator/SI.POV.GINI. 


\section{Appendix}

Table 7: Overview of Available Direct Democratic Instruments in European Democracies

\begin{tabular}{|c|c|c|c|}
\hline Country & Bottom-Up* & Top-Down** & Mandatory \\
\hline Andorra & No & Yes & Yes \\
\hline Austria & No & Yes & Yes \\
\hline Belgium & No & No & No \\
\hline Bulgaria & Yes & Yes & No \\
\hline Croatia & Yes & Yes & Yes \\
\hline Cyprus & No & No*** & No \\
\hline Cyprus (North) & No & Yes & No \\
\hline Czech Republic & No & No*** & No \\
\hline Denmark & No & Yes & Yes \\
\hline Estonia & & Yes & Yes \\
\hline Finland & No & Yes & No \\
\hline France & No & Yes & Yes \\
\hline Germany & No & No & Yes \\
\hline Gibraltar & No & Yes & Yes \\
\hline Greece & No & Yes & No \\
\hline Hungary & Yes & Yes & Yes \\
\hline Iceland & No & Yes & Yes \\
\hline Ireland & No & Yes & Yes \\
\hline Italy & Yes & Yes & No \\
\hline Latvia & Yes & Yes & Yes \\
\hline Liechtenstein & Yes & Yes & Yes \\
\hline Lithuania & Yes & Yes & Yes \\
\hline Luxembourg & Yes & Yes & No \\
\hline Malta & Yes & Yes & Yes \\
\hline Netherlands & No & No & No \\
\hline Norway & No & No*** & No \\
\hline Poland & No & Yes & No \\
\hline Portugal & Yes & Yes & Yes \\
\hline Romania & No & Yes & Yes \\
\hline Serbia & Yes & Yes & Yes \\
\hline Slovakia & Yes & Yes & Yes \\
\hline Slovenia & No & Yes & No \\
\hline Spain & No & Yes & Yes \\
\hline Sweden & No & Yes & No \\
\hline Switzerland & Yes & Yes & Yes \\
\hline United Kingdom & No & Yes & Yes \\
\hline
\end{tabular}

*Includes those that are listed as citizen initiative by IDEA

** Includes those that are listed as optional referendums by IDEA

$* * *$, but ad hoc referendums are possible

Source: https://www.idea.int/data-tools/data/direct-democracy 
Table 8: Comparison excluded, included and all bills

\begin{tabular}{|c|c|c|c|c|c|c|c|c|c|}
\hline \multirow[b]{2}{*}{ Region } & \multicolumn{3}{|c|}{ Excluded Cases } & \multicolumn{3}{|c|}{ Included Cases } & \multicolumn{3}{|c|}{ All Cases } \\
\hline & $\mathbf{N}$ & $\%$ & \% successful & $\mathbf{N}$ & $\%$ & \% successful & $\mathbf{N}$ & $\%$ & $\%$ successful \\
\hline Switzerland & 30 & 21,13 & 33,33 & 210 & 56,30 & 34,29 & 240 & 46,6 & 34,17 \\
\hline Scandinavia & 13 & 9,15 & 61,54 & 6 & 1,61 & 66,67 & 19 & 3,69 & 63,16 \\
\hline Eastern Europe & 44 & 30,99 & 43,18 & 55 & 14,75 & 21,82 & 99 & 19,22 & 31,31 \\
\hline Southern Europe & 32 & 22,54 & 46,88 & 53 & 14,21 & 33,96 & 85 & 16,5 & 38,82 \\
\hline $\begin{array}{l}\text { Central/Western } \\
\text { Europe }\end{array}$ & 23 & 16,2 & 60,87 & 49 & 13,14 & 46,94 & 72 & 13,98 & 51,39 \\
\hline total & 142 & 100 & 46,48 & 373 & 100 & 34,58 & 515 & 100 & 37,86 \\
\hline
\end{tabular}


Table 9: GINI Scores European Democracies 1990-2015

\begin{tabular}{|c|c|c|c|c|c|c|c|c|c|c|c|c|c|c|c|c|c|c|c|c|}
\hline \multirow[t]{2}{*}{ Country } & \multicolumn{20}{|c|}{ GINI Score (World Bank estimate, https://data.worldbank.org/indicator/SI.POV.GINI) } \\
\hline & 1990 & 1991 & 1992 & 1993 & 1994 & 1995 & 1996 & 1997 & 1998 & 1999 & 2000 & 2001 & 2002 & 2003 & 2004 & 2005 & 2006 & 2007 & 2008 & 2009 \\
\hline Andorra &. & & . & &. & &. & & . & & . & . & . & & & . & & & & \\
\hline Austria & . & . & . & . &. & . & . & & . & & . & . & . & 29,5 & 29,8 & 28,7 & 29,6 & 30,6 & 30,4 & 31,5 \\
\hline Bulgaria & . & . & 30,7 & . &. & &. & & . & & . & . & . & & . & . & 35,7 & 36,1 & 33,6 & 33,8 \\
\hline Croatia & . & . & . & . & . & 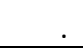 & . & . & . & & . & . & . & & & . & & & & 32,6 \\
\hline Cyprus & . & . & . & . & . & . & . & . & . & & . & . & . & & 30,1 & 30,3 & 31,1 & 31,1 & 31,7 & 32,1 \\
\hline $\begin{array}{l}\text { Czech } \\
\text { Republic }\end{array}$ & . & & & 26,6 & . & . & 25,8 & & . & & $\cdot$ & . & . & & 27,5 & 26,9 & 26,7 & 26 & 26,3 & 26,2 \\
\hline Denmark & . & &. & &. & &. & & . & & . & . & . & 25,6 & 24,9 & 25,2 & 25,9 & 26,2 & 25,2 & 26,7 \\
\hline Estonia & . & . & . & 39,5 &. & . & . & . & . & & . & . & . & 37,2 & 33,6 & 33,4 & 33,7 & 31,2 & 31,9 & 31,4 \\
\hline Finland & . & . &. & . &. & . &. & 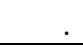 & . & & . & . & . & 27,7 & 27,9 & 27,6 & 28 & 28,3 & 27,8 & 27,5 \\
\hline France & . & . &. & . &. & . &. & . & . & & . & . & . & 31,4 & 30,6 & 29,8 & 29,7 & 32,4 & 33 & 32,7 \\
\hline Greece & . & . &. & . &. & . & . & . & . & & . & . & . & 32,8 & 33,6 & 34,6 & 35,1 & 34 & 33,6 & 33,6 \\
\hline Hungary & . & . & . & 27,9 &. & . & . & . & . & & . & . & . & & 29,9 & 34,7 & 28,3 & 27,9 & 27,5 & 27 \\
\hline Iceland & . & &. & . &. & 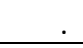 &. & & . & & . & . & . & 26,8 & 28 & 29 & 30,2 & 29,5 & 31,8 & 28,7 \\
\hline Ireland & . & . &. & . & . & . & . & . & . & & . & . & . & 32,9 & 33,6 & 33,7 & 32,7 & 31,9 & 30,9 & 32,7 \\
\hline Italy & . & . &. & . &. & . &. & . & . & & . & . & . & 34,9 & 34,3 & 33,8 & 33,7 & 32,9 & 33,8 & 33,8 \\
\hline Latvia & . & . &. & 27 &. & 31 & 31,6 & & . & & . & . & . & & 36,4 & 39 & 35,6 & 37,5 & 37,2 & 35,9 \\
\hline Liechtenstein & . & &. & & . & . & . & & . & & . & . & . & & . & . & . & & & \\
\hline Lithuania & . & . & . & 33,6 & . & . & . & . & . & . & . & . & . & & 37 & 35,3 & 34,4 & 34,8 & 35,7 & 37,2 \\
\hline Luxembourg & . & . &. & . &. & . &. & . & . & & . & . & . & 30,2 & 30,2 & 30,8 & 30,9 & 31,1 & 32,6 & 31,2 \\
\hline Malta & . & & & &. & & & & . & & 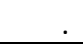 & . & . & & & . & 28 & 29,2 & 29 & 30,2 \\
\hline Netherlands & . & . &. & . &. & . &. & . & . & . & . & . & . & & 29,8 & 29 & 30 & 29,6 & 29,3 & 27,9 \\
\hline Norway & . & . &. & . &. & . &. & & . & & . & . & . & 27,6 & 31,6 & 30,6 & 26,4 & 27,1 & 27 & 26,2 \\
\hline Poland & . & . &. & 26,7 &. & . & 32,7 & & 32,3 & 32,6 & 33 & 32,8 & 34,1 & 34,9 & 35,4 & 34,5 & 33,7 & 33,5 & 33,7 & 33,6 \\
\hline Portugal & . & &. & . &. & . &. & . & . & & . & . & . & 38,7 & 38,9 & 38,5 & 38,1 & 36,7 & 36,6 & 34,9 \\
\hline Romania &. & &. & . & . & & & & 31,1 & 29,4 & 29,3 & 29,4 & 30,2 & 29,9 & 30 & 29,8 & 30,5 & 30,2 & 29,6 & 28,2 \\
\hline San Marino & . & & . & . & . & & . & & . & & & . & 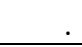 & & & . & & & & \\
\hline
\end{tabular}




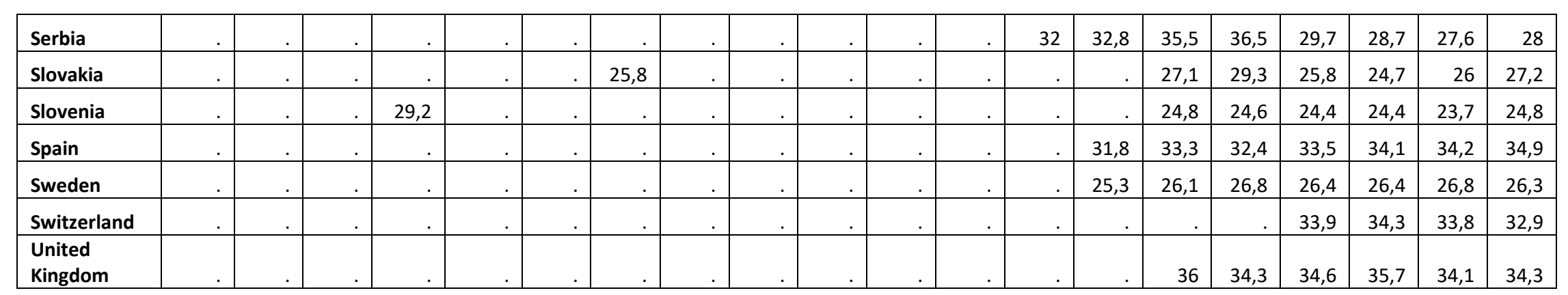

\begin{tabular}{|c|c|c|c|c|c|c|}
\hline \multirow{2}{*}{ Country } & \multicolumn{6}{|c|}{ GINI Score (World Bank estimate, https://data.worldbank.org/indicator/SI.POV.GINI) } \\
\hline & 2010 & 2011 & 2012 & 2013 & 2014 & 2015 \\
\hline \multicolumn{7}{|l|}{ Andorra } \\
\hline Austria & 30,3 & 30,8 & 30,5 & 30,8 & 30,5 & 30,5 \\
\hline Bulgaria & 35,7 & 34,3 & 36 & 36,6 & 37,4 & . \\
\hline Croatia & 32,4 & 32,3 & 32,5 & 32 & 32,1 & 30,8 \\
\hline Cyprus & 31,5 & 32,6 & 34,3 & 37 & 35,6 & 34 \\
\hline Czech Republic & 26,6 & 26,4 & 26,1 & 26,5 & 25,9 & 25,9 \\
\hline Denmark & 27,2 & 27,3 & 27,8 & 28,5 & 28,4 & 28,2 \\
\hline Estonia & 32 & 32,5 & 32,9 & 35,1 & 34,6 & 32,7 \\
\hline Finland & 27,7 & 27,6 & 27,1 & 27,2 & 26,8 & 27,1 \\
\hline France & 33,7 & 33,3 & 33,1 & 32,5 & 32,3 & 32,7 \\
\hline Greece & 34,1 & 34,8 & 36,2 & 36,1 & 35,8 & 36 \\
\hline Hungary & 29,4 & 29,2 & 30,8 & 31,5 & 30,9 & 30,4 \\
\hline Iceland & 26,2 & 26,8 & 26,8 & 25,4 & 25,6 & . \\
\hline Ireland & 32,3 & 32,9 & 33,2 & 33,5 & 31,9 & . \\
\hline Italy & 34,7 & 35,1 & 35,2 & 34,9 & 34,7 & . \\
\hline Latvia & 35 & 35,8 & 35,2 & 35,5 & 35,1 & 34,2 \\
\hline \multicolumn{7}{|l|}{ Liechtenstein } \\
\hline Lithuania & 33,6 & 32,5 & 35,1 & 35,3 & 37,7 & 37,4 \\
\hline
\end{tabular}




\begin{tabular}{|c|c|c|c|c|c|c|}
\hline Luxembourg & 30,5 & 32,1 & 34,3 & 32 & 31,2 & . \\
\hline Malta & 29 & 29,1 & 29,4 & 28,8 & 29 & \\
\hline Netherlands & 27,8 & 27,7 & 27,6 & 28,1 & 28,6 & 29,3 \\
\hline Norway & 25,7 & 25,3 & 25,7 & 26,4 & 26,8 & 27,5 \\
\hline Poland & 33,2 & 32,8 & 32,4 & 32,5 & 32,1 & 31,8 \\
\hline Portugal & 35,8 & 36,3 & 36 & 36,2 & 35,6 & 35,5 \\
\hline Romania & 28,2 & 27,2 & 27,3 & 27,5 & . & . \\
\hline \multicolumn{7}{|l|}{ San Marino } \\
\hline Serbia & 29 & & & 29 & . & 28,5 \\
\hline Slovakia & 27,3 & 26,5 & 26,1 & 28,1 & 26,1 & 26,5 \\
\hline Slovenia & 24,9 & 24,9 & 25,6 & 26,2 & 25,7 & 25,4 \\
\hline Spain & 35,2 & 35,7 & 35,4 & 36,2 & 36,1 & 36,2 \\
\hline Sweden & 26,5 & 26,9 & 27,1 & 27,8 & 28,4 & 29,2 \\
\hline Switzerland & 32,6 & 31,7 & 31,6 & 32,5 & 32,5 & \\
\hline United Kingdom & 34,4 & 33,2 & 32,3 & 33,2 & 34 & 33,2 \\
\hline
\end{tabular}




\section{Output and Bill Effects}

\section{Switzerland}

Table 10: Output Effects

\begin{tabular}{|l|l|l|l|l|}
\hline & Socio-economic & Political & Legal & Total \\
\hline Pro Equality (+1) & 12 & 0 & 2 & 14 \\
& $(16.67 \%)$ & $(0 \%)$ & $(2.78 \%)$ & $(19.44 \%)$ \\
\hline No effect (0) & 56 & 70 & 65 & 47 \\
& $(77.78 \%)$ & $(97.22 \%)$ & $(90.28 \%)$ & $(65.28 \%)$ \\
\hline Contra Equality (-1) & 4 & 2 & 5 & 11 \\
& $(5.56 \%)$ & $(2.78 \%)$ & $(6.94 \%)$ & $(15.28 \%)$ \\
\hline Total Bills & 72 & 72 & 72 & 72 \\
& $(100 \%)$ & $(100 \%)$ & $(100 \%)$ & $(100 \%)$ \\
\hline
\end{tabular}

Table 11: Bill Effects

\begin{tabular}{|l|l|l|l|l|}
\hline & Socio-economic & Political & Legal & Total \\
\hline Pro Equality (+1) & 40 & 2 & 12 & 54 \\
& $(19.05 \%)$ & $(0.95 \%)$ & $(5.71 \%)$ & $(25.71 \%)$ \\
\hline Not Related (0) & 158 & 206 & 184 & 128 \\
& $(75.24 \%)$ & $(98.10 \%)$ & $(87.62 \%)$ & $(60.95 \%)$ \\
\hline Contra Equality (-1) & 12 & 2 & 14 & 28 \\
& $(5.71 \%)$ & $(0.95 \%)$ & $(6.67 \%)$ & $(13.33 \%)$ \\
\hline Total Bills & 210 & 210 & 210 & 210 \\
& $(100 \%)$ & $(100 \%)$ & $(100 \%)$ & $(100 \%)$ \\
\hline
\end{tabular}

\section{Scandinavia ${ }^{29}$}

Table 12: Output Effects

\begin{tabular}{|l|l|l|l|l|}
\hline & Socio-economic & Political & Legal & Total \\
\hline Pro Equality (+1) & 0 & 2 & 1 & 3 \\
& $(0 \%)$ & $(50 \%)$ & $(25 \%)$ & $(75 \%)$ \\
\hline No effect (0) & 4 & 2 & 3 & 1 \\
& $(100 \%)$ & $(50 \%)$ & $(75 \%)$ & $(25 \%)$ \\
\hline Contra Equality (-1) & 0 & 0 & 0 & 0 \\
& $(0 \%)$ & $(0 \%)$ & $(0 \%)$ & $(0 \%)$ \\
\hline Total Bills & 4 & 4 & 4 & 4 \\
& $(100 \%)$ & $(100 \%)$ & $(100 \%)$ & $(100 \%)$ \\
\hline
\end{tabular}

Table 13: Bill Effects

\begin{tabular}{|l|l|l|l|l|}
\hline & Socio-economic & Political & Legal & Total \\
\hline Pro Equality (+1) & 0 & 2 & 1 & 3 \\
& $(0 \%)$ & $(33.33 \%)$ & $(16.67 \%)$ & $(50.00 \%)$ \\
\hline Not Related (0) & 6 & 4 & 5 & 3 \\
& $(100 \%)$ & $(66.67 \%)$ & $(83.33 \%)$ & $(50.00 \%)$ \\
\hline Contra Equality (-1) & 0 & 0 & 0 & 0 \\
& $(0 \%)$ & $(0 \%)$ & $(0 \%)$ & $(0 \%)$ \\
\hline
\end{tabular}

${ }^{29}$ Denmark, Finland, Iceland, Norway, Sweden 


\begin{tabular}{|l|l|l|l|l|}
\hline Total Bills & 6 & 6 & 6 & 6 \\
& $(100 \%)$ & $(100 \%)$ & $(100 \%)$ & $(100 \%)$ \\
\hline
\end{tabular}

\section{Eastern Europe ${ }^{30}$}

Table 14: Output Effects

\begin{tabular}{|l|l|l|l|l|}
\hline & Socio-economic & Political & Legal & Total \\
\hline Pro Equality (+1) & 3 & 0 & 0 & 3 \\
& $(25 \%)$ & $(0 \%)$ & $(0 \%)$ & $(25 \%)$ \\
\hline No effect (0) & 9 & 10 & 10 & 5 \\
& $(75 \%)$ & $(83.33 \%)$ & $(83.33 \%)$ & $(41.67 \%)$ \\
\hline Contra Equality (-1) & 0 & 2 & 2 & 4 \\
& $(0 \%)$ & $(16.67 \%)$ & $(16.67 \%)$ & $(33.33 \%)$ \\
\hline Total Bills & 12 & 12 & 12 & 12 \\
& $(100 \%)$ & $(100 \%)$ & $(100 \%)$ & $(100 \%)$ \\
\hline
\end{tabular}

Table 15: Bill Effects

\begin{tabular}{|l|l|l|l|l|}
\hline & Socio-economic & Political & Legal & Total \\
\hline Pro Equality (+1) & 6 & 3 & 7 & 16 \\
& $(10.91 \%)$ & $(5.45 \%)$ & $(12.73 \%)$ & $(29.09 \%)$ \\
\hline Not Related (0) & 48 & 46 & 43 & 27 \\
& $(87.27 \%)$ & $(83.64 \%)$ & $(78.18 \%)$ & $(49.09 \%)$ \\
\hline Contra Equality (-1) & 1 & 6 & 5 & 12 \\
& $(1.82 \%)$ & $(10.91 \%)$ & $(9.09 \%)$ & $(21.82 \%)$ \\
\hline Total Bills & 55 & 55 & 55 & 55 \\
& $(100 \%)$ & $(100 \%)$ & $(100 \%)$ & $(100 \%)$ \\
\hline
\end{tabular}

\section{Southern Europe ${ }^{31}$}

Table 16: Output Effects

\begin{tabular}{|l|l|l|l|l|}
\hline & Socio-economic & Political & Legal & Total \\
\hline Pro Equality (+1) & 0 & 1 & 1 & 2 \\
& $(0 \%)$ & $(5.56 \%)$ & $(5.56 \%)$ & $(11.11 \%)$ \\
\hline No effect (0) & 18 & 16 & 17 & 15 \\
& $(100 \%)$ & $(88.89 \%)$ & $(94.44 \%)$ & $(83.33 \%)$ \\
\hline Contra Equality (-1) & 0 & 1 & 0 & 1 \\
& $(0 \%)$ & $(5.56 \%)$ & $(0 \%)$ & $(5.56 \%)$ \\
\hline Total Bills & 18 & 18 & 18 & 18 \\
& $(100 \%)$ & $(100 \%)$ & $(100 \%)$ & $(100 \%)$ \\
\hline
\end{tabular}

Table 17: Bill Effects

\begin{tabular}{|l|l|l|l|l|}
\hline & Socio-economic & Political & Legal & Total \\
\hline Pro Equality (+1) & 0 & 5 & 3 & 8 \\
& $(0 \%)$ & $(9.43 \%)$ & $(5.66 \%)$ & $(15.09 \%)$ \\
\hline Not Related (0) & 51 & 45 & 50 & 40 \\
\hline
\end{tabular}

${ }^{30}$ Bulgaria, Croatia, Czech Republic, Estonia, Hungary, Latvia, Lithuania, Poland, Romania, Serbia, Slovakia, Slovenia

${ }^{31}$ Andorra, Cyprus, Greece, Italy, Malta, Portugal, San Marino, Spain 


\begin{tabular}{|l|l|l|l|l|}
\hline & $(96.23 \%)$ & $(84.91 \%)$ & $(94.34 \%)$ & $(75.47 \%)$ \\
\hline Contra Equality (-1) & 2 & 3 & 0 & 5 \\
& $(3.77 \%)$ & $(5.66 \%)$ & $(0 \%)$ & $(9.43 \%)$ \\
\hline Total Bills & 53 & 53 & 53 & 53 \\
& $(100 \%)$ & $(100 \%)$ & $(100 \%)$ & $(100 \%)$ \\
\hline
\end{tabular}

\section{Western Europe ${ }^{32}$}

Table 18: Output Effects

\begin{tabular}{|l|l|l|l|l|}
\hline & Socio-economic & Political & Legal & Total \\
\hline Pro Equality (+1) & 1 & 0 & 3 & 4 \\
& $(4.35 \%)$ & $(0 \%)$ & $(13.04 \%)$ & $(17.39 \%)$ \\
\hline No effect (0) & 22 & 23 & 18 & 17 \\
& $(95.65 \%)$ & $(100 \%)$ & $(78.26 \%)$ & $(73.91 \%)$ \\
\hline Contra Equality (-1) & 0 & 0 & 2 & 2 \\
& $(0 \%)$ & $(0 \%)$ & $(8.7 \%)$ & $(8.7 \%)$ \\
\hline Total Bills & 23 & 23 & 23 & 23 \\
& $(100 \%)$ & $(100 \%)$ & $(100 \%)$ & $(100 \%)$ \\
\hline
\end{tabular}

Table 19: Bill Effects

\begin{tabular}{|l|l|l|l|l|}
\hline & Socio-economic & Political & Legal & Total \\
\hline Pro Equality (+1) & 2 & 2 & 5 & 9 \\
& $(4.08 \%)$ & $(4.08 \%)$ & $(10.20 \%)$ & $(18.37 \%)$ \\
\hline Not Related (0) & 46 & 47 & 42 & 37 \\
& $(93.88 \%)$ & $(95.92 \%)$ & $(85.71 \%)$ & $(75.51 \%)$ \\
\hline Contra Equality (-1) & 1 & 0 & 2 & 3 \\
& $(2.04 \%)$ & $(0 \%)$ & $(4.08 \%)$ & $(6.12 \%)$ \\
\hline Total Bills & 49 & 49 & 49 & 49 \\
& $(100 \%)$ & $(100 \%)$ & $(100 \%)$ & $(100 \%)$ \\
\hline
\end{tabular}

\section{All Countries}

Table 20: Output Effects

\begin{tabular}{|l|l|l|l|l|}
\hline & Socio-economic & Political & Legal & Total \\
\hline Pro equality (+1) & 16 & 3 & 7 & 26 \\
& $(12.40 \%)$ & $(2.33 \%)$ & $(5.43 \%)$ & $(20.16 \%)$ \\
\hline No effect (0) & 109 & 121 & 113 & 85 \\
& $(84.50 \%)$ & $(93.80 \%)$ & $(87.60 \%)$ & $(65.89 \%)$ \\
\hline Contra equality (-1) & 4 & 5 & 9 & 18 \\
& $(3.10 \%)$ & $(3.88 \%)$ & $(6.98 \%)$ & $(13.95 \%)$ \\
\hline Total Bills & 129 & 129 & 129 & 129 \\
& $(100 \%)$ & $(100 \%)$ & $(100 \%)$ & $(100 \%)$ \\
\hline
\end{tabular}

Table 21: Bill Effects

\begin{tabular}{|l|l|l|l}
\hline Socio-economic & Political & Legal & Total
\end{tabular}

${ }^{32}$ Austria, France, Ireland, Liechtenstein, Luxembourg, Netherlands, United Kingdom 


\begin{tabular}{|l|l|l|l|l|}
\hline & & & & \\
\hline Pro equality (+1) & 48 & 14 & 28 & 90 \\
& $(12.87 \%)$ & $(3.75 \%)$ & $(7.51 \%)$ & $(24.13 \%)$ \\
\hline Not Related (0) & 309 & 348 & 324 & 235 \\
& $(82.84 \%)$ & $(93.30 \%)$ & $(86.86 \%)$ & $(63.00 \%)$ \\
\hline Contra Equality (-1) & 16 & 11 & 21 & 48 \\
& $(4.29 \%)$ & $(2.95 \%)$ & $(5.63 \%)$ & $(12.87 \%)$ \\
\hline Total Bills & 373 & 373 & 373 & 373 \\
& $(100 \%)$ & $(100 \%)$ & $(100 \%)$ & $(100 \%)$ \\
\hline
\end{tabular}

\section{Codebook:}

\begin{tabular}{|c|c|}
\hline Dimension & $\begin{array}{l}\text { Guiding Questions } \\
\text { (Code pro-equality if any of these questions can be answered with "yes") }\end{array}$ \\
\hline $\begin{array}{l}\text { 1. Socioeconomic } \\
\text { Equality }\end{array}$ & $\begin{array}{l}\text { 1.1) Does the bill propose measures that will increase income for } \\
\text { low SES groups? (i.e. raising the minimum wage, give tax cuts to } \\
\text { low income people, raising pensions etc.) } \\
\text { - 1.2) Does the bill propose measures that make (higher) education } \\
\text { more affordable for low SES groups? } \\
\text { - 1.3) Does the bill propose measures that make healthcare more } \\
\text { affordable for low SES groups? Does it lower patient contributions } \\
\text { in the health care sector? } \\
\text { 1.4) Does the bill propose measures that make housing more } \\
\text { affordable for low SES groups? (i.e. raising housing subsidies, } \\
\text { expand public housing, etc.) } \\
\text { 1.5) Does the bill propose measures that expand social welfare } \\
\text { programs? } \\
\text { 1.6) Does the bill propose measures that abolish/lower other } \\
\text { kinds of fees that are not proportionally rising with income? } \\
\text { 1.7) Does the bill propose measures to invest in common goods } \\
\text { mainly benefitting low SES groups? (e.g. public transportation) } \\
\text { 1.8) Does the bill propose measures that increase the retirement } \\
\text { age (if yes code contra-equality) }\end{array}$ \\
\hline 2. Political Equality & $\begin{array}{l}\text { - 2.1) Does the bill propose measures that strengthen the political } \\
\text { voice/powers of (political) minorities? }\end{array}$ \\
\hline
\end{tabular}

${ }^{33}$ Exception: 1.8 


\begin{tabular}{|c|c|c|}
\hline & - & $\begin{array}{l}\text { 2.2) Does the bill propose measures that lead to a more } \\
\text { proportional composition of parliament? (i.e. get rid of/weaken } \\
\text { majoritarian voting procedures, get rid of certain \% thresholds for } \\
\text { parliamentary elections) } \\
\text { 2.3) Does the bill propose measures that increase the media } \\
\text { presence of (political) minorities? Does it propose measures } \\
\text { against media monopolies of certain political actors? }\end{array}$ \\
\hline 3. Legal Equality & - & $\begin{array}{l}\text { 3.1) Does the bill propose measures that give more legal rights to } \\
\text { disadvantaged groups? (i.e. allowing same sex-marriage, allowing } \\
\text { adoption for same-sex couples, allowing permanent residents } \\
\text { without citizenship to vote in elections, etc.) } \\
\text { 3.2) Does the bill propose measures that facilitate the way to } \\
\text { citizenship? (i.e. for immigrants that are long term residents of the } \\
\text { country, for children of immigrants that were born/raised in the } \\
\text { country, etc.) } \\
\text { 3.3) Does the bill propose measures that give more rights to } \\
\text { immigrants/asylum seekers? Does it increase protection against } \\
\text { deportation? } \\
\text { 3.4) Does the bill propose measures that improve the legal status } \\
\text { of foreign residents of a country? (i.e. allow them to buy property, } \\
\text { allow them to work in certain professional fields, make them } \\
\text { eligible to apply for social welfare programs/unemployment } \\
\text { benefits, etc.) }\end{array}$ \\
\hline
\end{tabular}

Excluded cases:

99: EU/international treaties

98: direct democracy

97: age limits/crime

96: too complex to assess consequences

95: not enough information

94: independence/constitution 